\title{
Reviewing the Van Hiele model and the application of metacognition on geometric thinking
}

\author{
Muhammad Ammar Naufal', Abdul Halim Abdullah², Sharifah Osman ${ }^{3}$, Mohd Salleh Abu ${ }^{4}$, Hisyam \\ Ihsan $^{5}$, Rondiyah ${ }^{6}$ \\ ${ }^{1,2,3,4}$ School of Education, Faculty of Social Sciences and Humanities, Universiti Teknologi Malaysia, Malaysia \\ ${ }^{1,5}$ Faculty of Mathematics and Natural Sciences, Universitas Negeri Makassar, Indonesia
}

${ }^{6}$ SMA Negeri 5 Makassar, Indonesia

\section{Article Info}

Article history:

Received Nov 9, 2020

Revised Mar 30, 2021

Accepted Apr 12, 2021

\section{Keywords:}

Geometric thinking

Geometry

Metacognition

Systematic review

Van Hiele model

\begin{abstract}
Metacognition, or the ability to think about thinking, is essential in the development of geometric thinking. However, studies on the Van Hiele model and the application of metacognition on geometric thinking are still under-researched. This study aimed to provide a review of the Van Hiele model and the application of metacognition on geometric thinking. A total of 844 articles were retrieved through internet search engines from 1995 to 2020 and manually selected and reviewed systematically. The keywords used related to the Van Hiele model, metacognition, and geometric thinking. The findings that emerged from the review were categorized into two main themes which were the effectiveness of the Van Hiele model towards geometric thinking and the effectiveness of the application of metacognition on geometric thinking. Most articles revealed the positive indication of the geometric thinking development through the Van Hiele model intervention. It also seems that the potential of the application of metacognition in the Van Hiele model can strengthen geometric thinking development. Researchers and educators may find this knowledge useful in conducting empirical studies and developing learning instructions based on the application of metacognition in the development of geometric thinking.
\end{abstract}

This is an open access article under the CC BY-SA license.

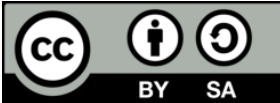

\section{Corresponding Author:}

Muhammad Ammar Naufal

School of Education, Faculty of Social Sciences and Humanities

Universiti Teknologi Malaysia

81310 Skudai, Johor Bahru, Johor, Malaysia

Email: mammarnaufal19@gmail.com

\section{INTRODUCTION}

One of the important elements in controlling the thinking process is metacognition. Students need to assess their capabilities in carrying out complex tasks and thinking about alternative work paths when the current work seems less effective and impasse [1], [2]. Also, students who use metacognition well will be critical thinkers, able to solve problems, and able to make good decisions compared to those who do not use their metacognition [3]. However, there are limited studies that focus on the application of metacognition in geometry [4] especially from the perspective of Van Hiele's learning phases and towards the development of student's geometric thinking [5], [6].

Geometric thinking is a branch of mathematics that can assist students in developing critical thinking skills [7]. It has been studied over the years by many experts [8]-[14]. No model, however, is more convincing than Van Hiele's geometric thinking model [15]-[17]. Accordingly, with the support of learning intervention, students' geometric thinking can develop through five levels hierarchically and eventually 
leading to formal deductive and rigor levels. Crowley [15] determined the levels as: Level 0 (Visualization) students recognize the whole shape from visual appearance without considering the components of the shape; Level 1 (Analysis) - students can notice the different shape by recognizing the attributes but not considered relevant; Level 2 (Informal Deductive) - students learn in identifying, classifying and using the relationship between attributes of shape; Level 3 (Formal Deductive) - students can make meaningful categorizations of shape and construct a proof regarding shape logically; and Level 4 (Rigor) - students can establish theorem within the axiomatic system and able to verify the effect of axiomatic manipulation.

Furthermore, Van Hiele's consideration of geometric thinking development is not solely based on the students' maturity level, but rather on their thinking abilities, vocabulary used, and learning experiences [18]-[20]. As a result, Van Hiele suggested five phases of learning. Usiskin [16] described the phases as: Information - teachers introduce new concepts to be taught, and students discuss how the original concepts relate to the new concepts being learned; Guided Orientation - teachers instruct the activities then students explore the guided activities; Explication - teachers convey the combination of shapes using the suitable language then students demonstrate their views on the task through discussion; Free Orientation - teachers provide the complex task then students solve the complex problems by themselves to see more clearly the relationship and attributes of shapes; Integration - teachers provide students with the ability to summarize what they have learned and prepare them to replicate the entire learning process in order to advance to the next level of geometric thinking. Hence, it is important to understand that the effectiveness of the intervention in developing geometric thinking required careful learning activities selection.

Several studies and interventions are carried out using different approaches and knowledge domains to explore the best way in improving geometric thinking. Among the learning approaches, some integrate with technologies [14], [21], [22], or manipulatives globally [7]. Metacognition is seen as one of the learning approaches that emphasize thinking skills [1], [23]. Some researchers [5], [6], [24] have begun to see the interconnectedness that occurs in the minds of students when given metacognitive interventions to develop their geometric thinking. Şefik, et al. [6], for instance, observe that students who are at the Level 1 cannot control their existing knowledge. In the meantime, at Level 4, students can control their knowledge and thought process. Hence, their findings indicate that metacognition may affect the development of geometric thinking.

As aforementioned, metacognition is one of the thinking skills that enable students to think their thinking process [25]. Organisation for Economic Co-operation and Development (OECD) [26] reveals that most studies on the impact of metacognition have been done on achievement in algebra and arithmetic in general. Several studies have investigated the effect of metacognition in geometry [27]-[29] and its overlapping in the Van Hiele model of geometric thinking [5], [6], [24]. However, there are few studies in viewing the application of metacognition from the perspective of geometric thinking. Yet, there has been no systematic review collecting papers related to the Van Hiele model and metacognition on geometric thinking development. Therefore, this study intends to review the existing literature regarding the Van Hiele model and the application of metacognition towards geometric thinking. This review also attempts to identify the effectiveness of the Van Hiele model and the application of metacognition in developing geometric thinking.

\section{RESEARCH METHOD}

The systematic review was selected to identify and evaluate the related studies on the Van Hiele model and metacognition in developing geometric thinking levels of students [30]. In this systematic review, the three phases used include planning, conducting, and reporting the review papers [31]. Once these three phases were carried out, the review results must be summed up, then the pattern of analysis needs to be identified and reported. The report needs to include the intervention and the patterning outcome of all the article reviews. Subsequently, it allows the application of the analytical critique component to synthesis discussions [32]. Figure 1 illustrates each phase of systematic review activities.

In the phase of the planning review, we prepared the research string using keywords: (Van Hiele) AND (Geometric Thinking) AND (Metacognition). The criteria for selection as shown in Table 1 was decided before searching the database and used for filtering text title, abstract, and the entire text.

The general terms were used for the first variable to examine the Van Hiele model that has been used and the application of metacognition or the integration of others' learning strategies or tools. The search string was carried out in international databases include Crossref, Springer, Science Direct, Google Scholar, ResearchGate, Scopus, and Web of Science. It was the leading database for research in educational multidisciplinary containing full-text publishing bibliographic records formats in various fields.

We found 844 articles in the conducting review phase that met the research questions of the study. The exclusion and inclusion criteria were used in the phase of analysis. In the phase of reporting the review, 
we then summarized the content into the table. The final number of articles that met the inclusion criteria was 29 articles. The review was reported in the results and discussions section.

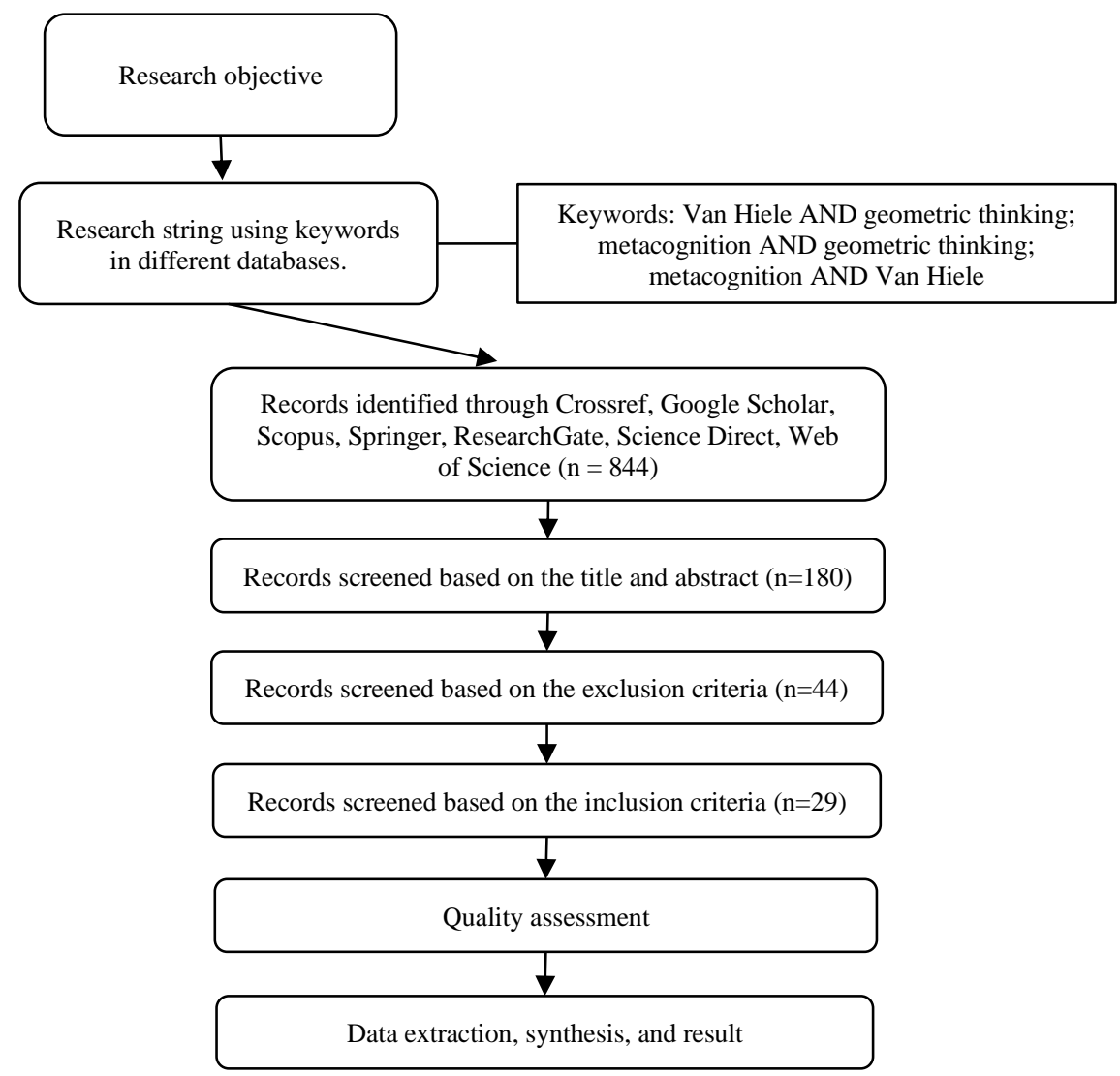

Figure 1. Flow chart for systematic reviews

Table 1. Exclusion and inclusion criteria

\begin{tabular}{cccc}
\hline Type of criteria & Criteria & Exclusion & Inclusion \\
\hline Publication & Journal papers & & $\mathrm{X}$ \\
& Conference papers & & $\mathrm{X}$ \\
& Thesis & & $\mathrm{X}$ \\
Books & $\mathrm{X}$ & \\
Access & Online & & $\mathrm{X}$ \\
& Offline printed & $\mathrm{X}$ & \\
Language & English & & $\mathrm{X}$ \\
& Others & $\mathrm{X}$ & \\
School level & Elementary & & $\mathrm{X}$ \\
& Secondary & & $\mathrm{X}$ \\
Period & 1990-2020 & & $\mathrm{X}$ \\
Study & Empirical & $\mathrm{X}$ \\
& Conceptual & $\mathrm{X}$ & \\
Research method & Experimental & $\mathrm{X}$ \\
& Survey & $\mathrm{X}$ & \\
& Quantitative & & $\mathrm{X}$ \\
& Qualitative & & $\mathrm{X}$ \\
& Mixed method & & $\mathrm{X}$ \\
\hline
\end{tabular}

\section{RESULTS AND DISCUSSION}

\subsection{The intervention and effectiveness of Van Hiele model on geometric thinking}

First, Table 2 demonstrates that 24 articles conducted the intervention using the Van Hiele model towards geometric thinking. 16 articles organized the intervention on secondary school students and seven on elementary school students. One article especially conducted the intervention on both elementary and secondary school levels. Four articles only used the Van Hiele model in intervening students' geometric 
thinking [33]-[36]. While other articles integrated the Van Hiele model with other learning approaches and aid tools. Furthermore, the majority of articles used experimental and quasi-experimental studies. Most articles revealed the improvement of the students' geometric thinking. It indicates that the Van Hiele model is feasible applied and expected benefits of incorporating learning approach as well as aid tools in developing students' geometric thinking at any school level of students.

Table 2. The retrieved articles on intervention of Van Hiele model towards geometric thinking

\begin{tabular}{|c|c|c|c|c|c|}
\hline No & Article & School level & $\begin{array}{l}\text { Research } \\
\text { method }\end{array}$ & Intervention & Main result \\
\hline 1 & [37] & Secondary & $\begin{array}{l}\text { Quasi- } \\
\text { experiment }\end{array}$ & $\begin{array}{l}\text { Instructional strategy (VH- } \\
\text { iSTEM) on geometric thinking } \\
\text { skills }\end{array}$ & $\begin{array}{l}\text { In the classroom, the VH-iSTEM learning method } \\
\text { can be used to help students develop their } \\
\text { geometric thinking skills. }\end{array}$ \\
\hline 2 & {$[38]$} & Secondary & $\begin{array}{l}\text { Experiment, } \\
\text { quantitative }\end{array}$ & $\begin{array}{l}\text { The tablet application with Van } \\
\text { Hiele's phase-based learning }\end{array}$ & $\begin{array}{l}\text { After learning with the tablet application, the } \\
\text { students' level of geometric thinking was higher } \\
\text { than after learning without it, allowing them to } \\
\text { reach level 3. (i.e., abstraction). }\end{array}$ \\
\hline 3 & [34] & Elementary & $\begin{array}{l}\text { True } \\
\text { experiment }\end{array}$ & $\begin{array}{l}\text { 1) Van Hiele's phases of } \\
\text { learning (VH-PL) module; 2) } \\
\text { Van Hiele's theory which is } \\
\text { integrated with the Google } \\
\text { SketchUp software (VH- GSU) } \\
\text { module; and 3) conventional } \\
\text { instruction (NVH-CI) module }\end{array}$ & $\begin{array}{l}\text { At the beginning of the experiment, the learners } \\
\text { were at the lower stages of Van Hiele's geometric } \\
\text { thinking. After the intervention, findings of the } \\
\text { WGT showed that most of the learners in all three } \\
\text { groups reached a higher degree of Van Hiele's } \\
\text { geometric thinking. }\end{array}$ \\
\hline 4 & [35] & Secondary & $\begin{array}{l}\text { Experiment, } \\
\text { quantitative }\end{array}$ & $\begin{array}{l}\text { Module using Van Hiele } \\
\text { theories for quadrilateral topics }\end{array}$ & $\begin{array}{l}\text { The module is practical to increase the student's } \\
\text { geometry thinking level by reaching Level } 2 \text { at } \\
\text { Van Hiele level. }\end{array}$ \\
\hline 5 & [21] & Secondary & $\begin{array}{l}\text { Quasi- } \\
\text { experiment, } \\
\text { quantitative }\end{array}$ & $\begin{array}{l}\text { Learning strategy based on Van } \\
\text { Hiele phases of learning and } \\
\text { visual thinking model through } \\
\text { SketchUp Make (SPPD-SUM) }\end{array}$ & $\begin{array}{l}\text { SPPD-SUM could help students improve their } \\
\text { visual spatial skills (VSS) and geometric thinking } \\
\text { (LGT). }\end{array}$ \\
\hline 6 & [19] & Secondary & $\begin{array}{l}\text { Mixed } \\
\text { method }\end{array}$ & $\begin{array}{l}\text { Constructing a learning } \\
\text { material for 3-dimensional Plan } \\
\text { and Elevation (namely LSPE- } \\
\text { SUM) }\end{array}$ & $\begin{array}{l}\text { The LSPE-SUM was effective in achieving its } \\
\text { goal of improving students' visual spatial skills and } \\
\text { Van Hiele's levels of geometric thinking. }\end{array}$ \\
\hline 7 & [39] & $\begin{array}{l}\text { Elementary } \\
\text { and } \\
\text { Secondary }\end{array}$ & $\begin{array}{l}\text { Experiment, } \\
\text { Mixed } \\
\text { method }\end{array}$ & The use of GeoGebra & $\begin{array}{l}\text { The effect of using GeoGebra was noted, the } \\
\text { performance improvement in transformation } \\
\text { geometry was shown, including the level of } \\
\text { development of Van Hiele's geometric thinking. }\end{array}$ \\
\hline 8 & [36] & Secondary & $\begin{array}{l}\text { Experiment, } \\
\text { Quantitative }\end{array}$ & $\begin{array}{l}\text { Van Hiele theory-based } \\
\text { geometry instruction }\end{array}$ & $\begin{array}{l}\text { The experimental group's output improved } \\
\text { significantly, with more students at level } 2 \text { than at } \\
\text { levels } 0 \text { and } 1 \text {, indicating that Van Hiele-based } \\
\text { learning had a beneficial impact on learners' } \\
\text { thought levels as compared to conventional } \\
\text { learning. }\end{array}$ \\
\hline 9 & [40] & Elementary & Experiment & $\begin{array}{l}\text { Van Hiele learning phases } \\
\text { using varied materials, concrete } \\
\text { experiences, and discussions }\end{array}$ & $\begin{array}{l}\text { Students who attended instruction did better on } 12 \\
\text { of the } 19 \text { tasks than students who did not receive } \\
\text { instruction. However, there was no substantial } \\
\text { difference in the number of points obtained at level } \\
0 \text {, level } 1.5 \text {, and level } 2 \text { of geometric thinking } \\
\text { between the two classes. }\end{array}$ \\
\hline 10 & [41] & Elementary & $\begin{array}{l}\text { Clinical } \\
\text { interview, } \\
\text { qualitative }\end{array}$ & $\begin{array}{l}\text { Physical models of geometrical } \\
\text { solids undergo dynamic } \\
\text { transformations. }\end{array}$ & $\begin{array}{l}\text { The research showed a progression from } \\
\text { perceptual considerations to solid geometry. While } \\
\text { not all children achieved a higher level of thought, } \\
\text { the dynamic transformation environment aided the } \\
\text { growth of a significant portion of a child's } \\
\text { geometric thinking. }\end{array}$ \\
\hline 11 & [42] & Secondary & $\begin{array}{l}\text { Experiment, } \\
\text { quantitative }\end{array}$ & $\begin{array}{l}\text { Dynamic Geometry Software- } \\
\text { Assisted Instruction }\end{array}$ & $\begin{array}{l}\text { Supported Learning when compared to traditional } \\
\text { teaching, Dynamic Geometry Software has a } \\
\text { positive effect on student mathematics } \\
\text { achievement in the transition of geometry and } \\
\text { geometric thinking. }\end{array}$ \\
\hline 12 & [9] & Secondary & $\begin{array}{l}\text { Quasi- } \\
\text { experiment, } \\
\text { qualitative }\end{array}$ & $\begin{array}{l}\text { Van Hiele's learning phases } \\
\text { using the Geometer's } \\
\text { Sketchpad (GSP) }\end{array}$ & $\begin{array}{l}\text { The treatment participants displayed complete Van } \\
\text { Hiele level } 1 \text { acquisition, and nearly all of them } \\
\text { showed complete Van Hiele level } 2 \text { acquisition. In } \\
\text { contrast, only one student did not achieve level } 3 \text {, } \\
\text { while the others demonstrated full and high levels } \\
\text { of acquisition. As a result, it can be inferred that } \\
\text { implementing Van Hiele geometry learning } \\
\text { activities has a positive effect on the progression } \\
\text { of greater levels of geometric thinking. }\end{array}$ \\
\hline
\end{tabular}


Table 2. The retrieved articles on intervention of Van Hiele model towards geometric thinking (continued)

\begin{tabular}{|c|c|c|c|c|c|}
\hline No & Article & School level & $\begin{array}{l}\text { Research } \\
\text { method }\end{array}$ & Intervention & Main result \\
\hline 13 & [13] & Elementary & $\begin{array}{l}\text { Experiment, } \\
\text { quantitative }\end{array}$ & $\begin{array}{l}\text { Van Hiele's learning phases } \\
\text { using tangrams }\end{array}$ & $\begin{array}{l}\text { Van Hiele's tangram-based learning phase } \\
\text { significantly improved geometrical thinking in the } \\
\text { first (visual) and second (analysis) levels among } \\
\text { high-, medium-, and low-ability students. }\end{array}$ \\
\hline 14 & [43] & Elementary & Quantitative & Using Geometer's Sketchpad & $\begin{array}{l}\text { After two weeks of intervention, the geometric } \\
\text { reasoning skill of Van Hiele students using } \\
\text { Geometer's Sketchpad was not substantially } \\
\text { different from the control group. }\end{array}$ \\
\hline 15 & [14] & Secondary & $\begin{array}{l}\text { Quasi- } \\
\text { experiment, } \\
\text { quantitative }\end{array}$ & $\begin{array}{l}\text { Video based on Van Hiele } \\
\text { model }\end{array}$ & $\begin{array}{l}\text { Most of the students have seen a major change in } \\
\text { their geometric thinking abilities. }\end{array}$ \\
\hline 16 & {$[11]$} & Elementary & $\begin{array}{l}\text { exploratory } \\
\text { case study }\end{array}$ & $\begin{array}{l}\text { Based on the Van Hiele theory } \\
\text { of geometric thinking, phase- } \\
\text { based instruction using The } \\
\text { Geometer's Sketchpad (GSP) is } \\
\text { used }\end{array}$ & $\begin{array}{l}\text { The treatment had significantly improved the } \\
\text { student's geometric thinking regarding the regular } \\
\text { polygons. }\end{array}$ \\
\hline 17 & [22] & Secondary & $\begin{array}{l}\text { Quasi- } \\
\text { experiment }\end{array}$ & $\begin{array}{l}\text { Van Hiele's learning phases } \\
\text { using the GSP }\end{array}$ & $\begin{array}{l}\text { Students in the experimental group performed } \\
\text { better than students in the control group in terms } \\
\text { of geometric thinking }(\mathrm{t}=34.50, \mathrm{p} 0.05) \text {. }\end{array}$ \\
\hline 18 & [33] & Secondary & $\begin{array}{l}\text { Quasi- } \\
\text { experiment, } \\
\text { Mixed } \\
\text { method }\end{array}$ & $\begin{array}{l}\text { Van Hiele's phase-based } \\
\text { learning }\end{array}$ & $\begin{array}{l}\text { The treatment group's students displayed complete } \\
\text { acquisition of the Van Hiele levels, with nearly all } \\
\text { of them demonstrating complete acquisition of the } \\
\text { second level. Just one student did not achieve level } \\
\text { three, while the others demonstrated a full and } \\
\text { high level of acquisition. }\end{array}$ \\
\hline 19 & [44] & Secondary & Case study & $\begin{array}{l}\text { Based on the Van Hiele theory, } \\
\text { phase-based instruction with } \\
\text { manipulatives and The } \\
\text { Geometer's Sketchpad (GSP) is } \\
\text { used }\end{array}$ & $\begin{array}{l}\text { The intervention has the potential to improve } \\
\text { students' geometric thinking and strong geometry } \\
\text { achievement. }\end{array}$ \\
\hline 20 & [45] & Secondary & $\begin{array}{l}\text { Quasi- } \\
\text { experiment }\end{array}$ & Using geometers' sketchpad & $\begin{array}{l}\text { The use of the Geometer Sketchpad and Van } \\
\text { Hiele-based teaching materials played an } \\
\text { important role in assisting students in improving } \\
\text { their geometric thinking on one level or to a higher } \\
\text { level. }\end{array}$ \\
\hline 21 & [46] & Secondary & Case study & $\begin{array}{l}\text { Based on the Van Hiele theory, } \\
\text { a phase-based instructional } \\
\text { environment using Geometer's } \\
\text { Sketchpad (GSP) }\end{array}$ & $\begin{array}{l}\text { After the phase-based instruction with GSP, Van } \\
\text { Hiele levels stayed the same or increased slightly. }\end{array}$ \\
\hline 22 & [47] & Secondary & Experiment & $\begin{array}{l}\text { Interactive Geometry software } \\
\text { (IGS) }\end{array}$ & $\begin{array}{l}\text { The students were also able to enter the third level } \\
\text { of geometric thinking. The post-test results } \\
\text { showed that the geometric thinking students } \\
\text { improved significantly after using the module. }\end{array}$ \\
\hline 23 & [48] & Secondary & $\begin{array}{l}\text { Quasi- } \\
\text { experiment }\end{array}$ & Using Geometers' Sketchpad & $\begin{array}{l}\text { Students progressed in one level or to a higher } \\
\text { level due to Van Hiele-based teaching materials } \\
\text { and the use of Geometer Sketchpad. }\end{array}$ \\
\hline 24 & [49] & Elementary & Experiment & $\begin{array}{l}\text { GeoCAL based on Van Hiele's } \\
\text { geometric thinking level theory }\end{array}$ & $\begin{array}{l}\text { GeoCAL developed important learning effects on } \\
\text { visual association, analysis/description, } \\
\text { relation/abstraction, and geometric thinking in } \\
\text { general, in addition to recognition capabilities. }\end{array}$ \\
\hline
\end{tabular}

To assist students in attaining a higher level of geometric thinking, Hassan, et al. [37] used an instructional approach focused on Science, Technology, Engineering, and Mathematics (STEM) that was combined with the Van Hiele model (namely VH-iSTEM). The students collaboratively underwent geometry learning, using interrogative questions, sharing ideas, and helping peers discovered their own learning experiences for 80 minutes using lesson activities based on the VH-iSTEM. The students were provided scaffolding by the teacher who acted as a facilitator.

Others used the Van Hiele model integrated with aid tools such as Dynamic Geometry Software [42], GeoGebra [39], GSP [9], [11], [22], [43]-[46], [48], GeoCal [49], Tangram [13], Interactive Geometry Software [47], SketchUp Make [19], [21], [34], Video [14], and Tablet application [38]. They used the technology as an aid in facilitating the teaching of geometric topics to students. Their studies reported on the benefits of using technology in cultivating students' geometric thinking. The technology helped to scaffold the learning and teaching process based on the Van Hiele model. It allows the users to develop knowledge on geometry and easily visualize two- and three-dimensional objects [14], [21], [39]. This is because the ability of technology is easy to manipulate and manage, making it easier for students to understand a concept compared to conventional learning [50]. 
Moreover, Markopoulos, et al. [41] as well as Škrbec and Čadež [40] used varied materials and concrete experiences in developing students' geometric thinking. However, Markopoulos, et al. [41] found that not all students achieved an advanced level of thinking. Also, according to the findings of Skrbec and Čadež [40], there was no substantial difference between the two groups in terms of the level reached, such as the number of points at level 0, level 1.5, and level 2. Because according to Škrbec and Čadež [40], the students have problems using suitable terminology during exploring the materials and concrete in geometry. Tieng and Eu [43] found no substantial difference in improvement between the experiment and control groups after the GSP intervention. This may be due to the intervention's brief duration. Nonetheless, the proposed technology, when used in conjunction with the Van Hiele model, provides numerous benefits for the advancement of geometric thinking [50], [51].

Based on the review, the findings revealed that the Van Hiele model plays a significant role in developing the geometric thinking level of students. Although the majority of studies integrated the use of technology in the Van Hiele model, we cannot conclusively say that the aid tools used are better than the Van Hiele learning phases or other learning approaches, yet it depends on how teachers and students operate the aid tools following each level of geometric thinking. Also, the most prominent methods used to examine the development of geometric thinking is through experimental study then quasi-experimental study. It could be said that most of the papers reviewed have studied the effectiveness of the Van Hiele model towards geometric thinking development and compared it to conventional or other types of learning approaches such as incorporating with aid tools.

\subsection{The intervention and effectiveness of the application of metacognition on geometric thinking}

Second, there are only five articles suited to the research question that performed the application of metacognition compared to the Van Hiele model regarding geometric thinking as shown in Table 3. Two respective articles were conducted at the elementary and secondary school levels. The focus of studies in the Van Hiele model with metacognitive has shown its effectiveness on student progression of geometric thinking. All the articles revealed the positive performance of students' geometric thinking. However, there are still only a few studies examining the performance of the application of metacognitive in the Van Hiele model through experimental methods [51]. While others [5], [24], [52] are still trying to explore more deeply the relationship between geometric thinking and metacognitive in affecting the development of students' geometric thinking.

Table 3. Overview of the retrieved articles on metacognition towards geometric thinking

\begin{tabular}{|c|c|c|c|c|c|}
\hline No & Article & School level & $\begin{array}{c}\text { Research } \\
\text { method }\end{array}$ & Intervention & Main result \\
\hline 1 & [52] & Secondary & Qualitative & Metacognition & $\begin{array}{l}\text { In Indonesia and Thailand, visual level students may already } \\
\text { think about what to do during the planning stage, but during } \\
\text { the monitoring stage, students question the problem's } \\
\text { meaning. However, during the assessment period, they } \\
\text { continued to have doubts about their decision. At the } \\
\text { preparation, tracking, and assessment stages in Indonesia and } \\
\text { Thailand, analysis level students knew just what they were } \\
\text { saying. }\end{array}$ \\
\hline 2 & [6] & Secondary & Quantitative & $\begin{array}{l}\text { Geometric thinking } \\
\text { on metacognition }\end{array}$ & $\begin{array}{l}\text { The study found that all learners' geometric thinking levels in } \\
\text { the Van Hiele model affect their metacognitive skills. }\end{array}$ \\
\hline 3 & [24] & Elementary & Qualitative & $\begin{array}{l}\text { Metacognition on } \\
\text { the thinking level } \\
\text { of informal } \\
\text { deduction }\end{array}$ & $\begin{array}{l}\text { The metacognition process that emerges from the students at } \\
\text { the informal deductive thinking level is focusing more on } \\
\text { planning to cultivate their understanding and knowledge in } \\
\text { the form of full visibility and visualization of problems into } \\
\text { simpler forms. Students are more likely to use visual } \\
\text { knowledge monitoring to apply their initial knowledge to the } \\
\text { issue during the monitoring process. Students select and } \\
\text { define solutions that can be used to determine the outcome of } \\
\text { problem-solving during the evaluation process. }\end{array}$ \\
\hline 4 & {$[51]$} & Elementary & $\begin{array}{l}\text { Experiment, } \\
\text { pilot study }\end{array}$ & $\begin{array}{l}\text { Using an aid tool } \\
\text { called Kindergarten } \\
\text { Social Assistive } \\
\text { Robot (KindSAR) }\end{array}$ & $\begin{array}{l}\text { When they 'played' with the robot, they improved their } \\
\text { geometric thinking and metacognitive abilities. }\end{array}$ \\
\hline 5 & [5] & Secondary & $\begin{array}{l}\text { Exploratory, } \\
\text { qualitative }\end{array}$ & $\begin{array}{l}\text { Metacognition on } \\
\text { Van Hiele model of } \\
\text { geometric thinking }\end{array}$ & $\begin{array}{l}\text { Students who are given an objective test such as the Van } \\
\text { Hiele Geometry Test do not seem to score as high as students } \\
\text { who are interviewed. Meaning that the students who were } \\
\text { interviewed metacognitively showed the progression of Van } \\
\text { Hiele level and seem to fit the Van Hiele level } 1 \text { and level } 2 \text {. }\end{array}$ \\
\hline
\end{tabular}


An early study on metacognition upon geometric thinking had done by Finnell [5] in 1992. Followed by [24], [51], [52] who also studied geometric thinking by using metacognition. Moreover, the exploration of students' metacognition seems to suit Van Hiele level 1 and level 2 according to Finnell [5]. The students demonstrated the progression of geometric thinking after undergoing a metacognitive interview session. It is supported by Rofii, et al. [24] who studied the metacognition on informal deduction level shown that the students' metacognition emerged at the informal deductive level. In the planning process, the learners focused more on cultivating their understanding and knowledge to visualize the problems into simpler forms. In the monitoring process, the students related based on visual knowledge monitoring their prior knowledge to the problem. In the evaluation process, the students chose and identified alternative solutions for the result of problem-solving. However, Firmansyah, et al. [52] who studied the comparison between Indonesian and Thailand students shown that both countries' students doubted deciding to solve the problems in the evaluation process. Interestingly, Keren and Fridin [51] used metacognition in conjunction with the Social Assistive Robot (KindSAR) to help improve geometric thinking. Not only did students' geometric thinking improve, but their metacognition also improved. This is consistent with the findings of Şefik, et al. [6] demonstrated that as students' metacognitive skill scores increased, so did their Van Hiele geometric thinking levels. Their findings indicated that the role of metacognition as a controlling cognitive skill, which is geometric thinking, plays an important role. As experts [1], [25] point out that metacognition skills allow students to plan, monitor, and evaluate their thinking.

Overall, the effects of using the Van Hiele model and metacognition to improve geometric thinking have been promising. It is shown that the integration of other learning approaches and aid tools has improved the students' geometric thinking. The studies regarding the Van Hiele model found that the most frequently reported are the experimental and quasi-experimental designs. The influence of the Van Hiele model, especially the effect of metacognition application on the Van Hiele model of geometric thinking, is better understood through qualitative design research. However, research into the role of metacognition in Van Hiele's geometric thinking is still in its early stages. In fact, if we look at the findings of several previous researchers who have tried to see the relationship between metacognition and the Van Hiele model, there is a potential for increasing students' geometric thinking [5], [6], [51]. It may work because metacognition influences the way students think about their cognition in planning, monitoring, and evaluating each step of their work [1]. Students who can control their thinking tend to be in line with the improvement of their geometric thinking [5]. Nevertheless, it needs more empirical studies to be conducted regarding the application of the Van Hiele model incorporated with metacognition on geometric thinking in which there is a potential and overlapping between them to strengthen the increment of geometric thinking.

\section{CONCLUSION}

The Van Hiele model was frequently used and showed a positive impact in developing geometric thinking as a learning approach whether as a single intervention or integrating with other learning approaches or help tools in most of the studies reviewed that implementing the Van Hiele model and the application of metacognition on geometric thinking. Meanwhile, empirical studies of the application of metacognition in the development of geometric thinking are scarce. Integration of the Van Hiele model with the application of metacognition has the potential to improve geometric thinking development. As a result, it is proposed that more empirical studies be conducted that have a greater effect on the Van Hiele model and the application of metacognition in geometric thinking. It is also recommended that future studies in learning geometry provide the help tools' feature for exploring geometry concepts and tasks.

\section{ACKNOWLEDGEMENTS}

The authors would like to thank the Ministry of Education and Universiti Teknologi Malaysia for their financial support. This work was supported by the GUP Tier 2 Grant no. Q.J130000.2653.16J12.

\section{REFERENCES}

[1] J. Garofalo and F. K. Lester, "Metacognition, Cognitive Monitoring, and Mathematical Performance," J. Res. Math. Educ., vol. 16, no. 3, pp. 163-176, May 1985, doi: 10.2307/748391.

[2] A. H. Schoenfeld, "What's All the Fuss About Metacognition?" Cogn. Sci. Math. Educ., vol. 189, p. $215,1987$.

[3] I. M. Nurlailiyah, "Improving students' mathematical metacognition skills with a realistic approach in learning mathematics (in Bahasa)," Thesis, Universitas Pendidikan Indonesia, 2013.

[4] Z. Mevarech and B. Kramarski, Critical Maths for Innovative Societies: The Role of Metacognitive Pedagogies. OECD, 2014. 
[5] L. Finnell, "Metacognition and the Van Hiele model of thinking in geometry," Dissertation, Georgia State University, 1992.

[6] Ö. Şefik, S. Urhan, and N. Sezen-Yüksel, "Analysis of metacognitive skills and Van Hiele levels of geometric thinking through various variables," in AIP Conference Proceedings, vol. 2037, 2018, doi: 10.1063/1.5078479.

[7] M. N. Hassan, A. H. Abdullah, and N. Ismail, "Effects of Integrative Interventions with Van Hiele Phase on Students' Geometric Thinking: A Systematic Review," J. Crit. Rev., vol. 7, no. 13, pp. 1133-1140, Jul. 2020, doi: 10.31838/jcr.07.13.194.

[8] Z. Ismail and S. N. A. Rahman, "Learning 2-Dimensional and 3-Dimensional Geometry With Geogebra: Which Would Students Do Better?" Int. J. Emerg. Math. Educ., vol. 1, no. 2, pp. 121-134, 2017, doi: 10.12928/ijeme.v1i2.5541.

[9] A. H. Abdullah and E. Zakaria, "The Effects of Van Hiele's Phases of Learning Geometry on Students' Degree of Acquisition of Van Hiele Levels," Procedia - Soc. Behav. Sci., vol. 102, pp. 251-266, Nov. 2013, doi: 10.1016/j.sbspro.2013.10.740.

[10] R. B. Armah and P. S. Kissi, "Use of the Van Hiele Theory in Investigating Teaching Strategies used by College of Education Geometry Tutors," EURASIA J. Math. Sci. Technol. Educ., vol. 15, no. 4, Jan. 2019, doi: 10.29333/ejmste/103562.

[11] C. C. Meng and L. C. Sam, "Enhancing primary pupils' geometric thinking through phase-based instruction using the Geometer's Sketchpad," Asia Pacific J. Educ. Educ., vol. 28, pp. 33-51, 2013.

[12] J. Haviger and I. Vojkůvková, "The Van Hiele Levels at Czech Secondary Schools," Procedia - Soc. Behav. Sci., vol. 171, pp. 912-918, 2015, doi: 10.1016/j.sbspro.2015.01.209.

[13] N. M. Siew, C. L. Chong, and M. R. Abdullah, "Facilitating Students' Geometric Thinking Through Van Hiele's Phase-Based Learning Using Tangram," J. Soc. Sci., vol. 9, no. 3, pp. 101-111, 2013, doi: 10.3844/jsssp.2013.101.111.

[14] M. S. Abu and Z. Z. Abidin, "Improving the Levels of Geometric Thinking of Secondary School Students Using Geometry Learning Video based on Van Hiele Theory," Int. J. Eval. Res. Educ. (IJERE), vol. 2, no. 1, pp. 16-22, 2013. [Online]. Available: http://ijere.iaescore.com/index.php/IJERE/article/view/4434.

[15] M. L. Crowley, "The Van Hiele model of the development of geometric thought," in M. M. Lindquist, Ed., Learning and Teaching Geomretry, K-12. Reston, Va: National Council of Teachers of Mathematics, 1987, pp. $1-16$.

[16] Z. Usiskin, "Van Hiele Levels and Achievement in Secondary School Geometry," National Inst. of Education (ED), Washington, DC. 1982. [Online]. Available: http://files.eric.ed.gov/fulltext/ED220288.pdf.

[17] D. H. Clements and M. T. Battista, "Geometry and Spatial Reasoning," in D. A. Grouws, Ed., Handbook of research on mathematics teaching and learning. New York: Macmillan, 1992, pp. 420-464.

[18] R. B. Armah, P. O. Cofie, and C. A. Okpoti, "Investigating the effect of Van Hiele phase-based instruction on preservice teachers' geometric thinking," Int. J. Res. Educ. Sci., vol. 4, no. 1, 2018, doi: 10.21890/ijres.383201.

[19] R. A. Wahab, A. H. Abdullah, M. Mokhtar, N. A. Atan, and M. S. Abu, "Evaluation by Experts and Designated Users on the Learning Strategy using SketchUp Make for Elevating Visual Spatial Skills and Geometry Thinking," Bolema Bol. Educ. Matemática, vol. 31, no. 58, pp. 819-840, Aug. 2017, doi: 10.1590/1980-4415v31n58a15.

[20] P. M. Van Hiele, "Developing Geometric Thinking through Activities That Begin with Play," in Teaching Children Mathematics. NCTM, 1999, pp. 310-316.

[21] R. A. Wahab, A. H. Abdullah, M. S. Abu, N. A. Atan, M. Mokhtar, and M. H. Hamzah, "A Learning 3D Geometry through Sketchup Make (SPPD-SUM) to Enhance Visual Spatial Skills and the Level of Geometric Thinking," $J$. Fundam. Appl. Sci., vol. 10, no. 6S, pp. 1005-1039, 2018, doi: 10.4314/jfas.v10i1s.36.

[22] A. H. Abdullah and E. Zakaria, "The Effects of Van Hiele's Phase-Based Instruction Using the Geometer's Sketchpad (GSP) on Students' Levels of Geometric Thinking," Res. J. Appl. Sci. Eng. Technol., vol. 5, no. 5, pp. 1652-1660, 2013.

[23] M. V. J. Veenman, B. H. A. M. Van Hout-Wolters, and P. Afflerbach, "Metacognition and learning: Conceptual and methodological considerations," Metacognition Learn., vol. 1, no. 1, pp. 3-14, 2006, doi: 10.1007/s11409-0066893-0.

[24] A. Rofii, S. Sunardi, and M. Irvan, "Characteristics of Students' Metacognition Process at Informal Deduction Thinking Level in Geometry Problems," Int. J. Emerg. Math. Educ., vol. 2, no. 1, p. 89, Feb. 2018, doi: 10.12928/ijeme.v2i1.7684.

[25] J. H. Flavell, "Metacognition and cognitive monitoring: A new area of cognitive-developmental inquiry," Am. Psychol., vol. 34, no. 10, pp. 906-911, 1979, doi: 10.1037/0003-066x.34.10.906.

[26] OECD, "The effects of metacognitive instruction on achievement," Critical Maths for Innovative Societies: The Role of Metacognitive Pedagogies. OECD.org, 2014.

[27] S. Mandaci Şahin and F. Kendir, "The Effect of Using Metacognitive Strategies for Solving Geometry Problems on Students' Achievement and Attitude," Educ. Res. Rev., vol. 8, no. 19, pp. 1777-1792, 2013, doi: 10.5897/ERR2013.1578.

[28] S. Miller and S. William, "The Impact of Metacognitive Teaching Strategies on Learners' Performance in Earth Geometry: A Case Study of Mubanga Secondary School," Int. J. Res. Innov. Soc. Sci., vol. 3, no. 10, pp. 2454-6186, 2019. [Online]. Available: www.rsisinternational.org.

[29] D. Patkin and Y. Sarfaty, "The Effect of Solid Geometry Activities of Pre-service Elementary School Mathematics Teachers on Concepts Understanding and Mastery of Geometric Thinking Levels," J. Korean Soc. Math. Educ. Ser. D Res. Math. Educ., vol. 16, no. 1, pp. 31-50, 2012. 
[30] A. P. Siddaway, A. M. Wood, and L. V. Hedges, "How to Do a Systematic Review: A Best Practice Guide for Conducting and Reporting Narrative Reviews, Meta-Analyses, and Meta-Syntheses," Annu. Rev. Psychol., vol. 70, no. 1, pp. 747-770, Jan. 2019, doi: 10.1146/annurev-psych-010418-102803.

[31] B. Kitchenham and S. Charters, "Guidelines for performing systematic literature reviews in software engineering," EBSE 2007-001. Keele University and Durham University Joint Report, 2007. [Online]. Available: https://www.elsevier.com/_data/promis_misc/525444systematicreviewsguide.pdf.

[32] C. Hart, Doing a Literature Review: Releasing the Social Science Research Imagination. SAGE Publications, 2018.

[33] A. H. Abdullah and E. Zakaria, "Enhancing Students' Level of Geometric Thinking Through Van Hiele's Phasebased Learning," Indian J. Sci. Technol., vol. 6, no. 5, pp. 1-15, 2013.

[34] A. S. Md. Yunus, A. F. Mohd Ayub, and T. T. Hock, "Geometric Thinking of Malaysian Elementary School Students," Int. J. Instr., vol. 12, no. 1, pp. 1095-1112, Jan. 2019, doi: 10.29333/iji.2019.12170a.

[35] D. Argaswari, "Development of Module of Leanring Geometry Based on Van Hiele Theory," J. Daya Mat., vol. 6, no. 3, p. 276, 2019, doi: 10.26858/jds.v6i3.8528.

[36] J. K. Alex and K. J. Mammen, "Lessons Learnt from Employing Van Hiele Theory Based Instruction in Senior Secondary School Geometry Classrooms," Eurasia J. Math. Sci. Technol. Educ., vol. 12, no. 10, pp. 2223-2236, 2016, doi: 10.12973/eurasia.2016.1228a.

[37] M. N. Hassan, A. H. Abdullah, and N. Ismail, "Effects of VH-iSTEM Learning Strategy on Basic Secondary School Students' Degree of Acquisition of Van Hiele Levels of Thinking in Sokoto State, Nigeria," Univers. J. Educ. Res., vol. 8, no. 9, pp. 4213-4223, 2020, doi: 10.13189/ujer.2020.080948.

[38] L. Adulyasas, "Transferring Van Hiele Phase based Earning to the Tablet Application for Enhancing Secondary Student's Geometric Thinking," J. Adv. Res. Dyn. Control Syst., vol. 12, no. SP4, pp. 8-15, Mar. 2020, doi: 10.5373/JARDCS/V12SP4/20201460.

[39] G. R. Kekana, "Using GeoGebra in transformation geometry: an investigation based on the Van Hiele model," Master Dissertation, University of Pretoria, 2016.

[40] M. Škrbec and T. H. Čadež, "Identifying and Fostering Higher Levels of Geometric Thinking," Eurasia J. Math. Sci. Technol. Educ., vol. 11, no. 3, pp. 601-617, Jun. 2015, doi: 10.12973/eurasia.2015.1339a.

[41] C. Markopoulos, D. Potari, W. Boyd, K. Petta, and M. Chaseling, "The Development of Primary School Students' 3D Geometrical Thinking within a Dynamic Transformation Context," Creat. Educ., vol. 6, no. 6, pp. 1508-1522, 2015, doi: 10.4236/ce.2015.614151.

[42] M. B. Akgül, "The Effect of Using Dynamic Geometry Software on Eight Grade Students' Achievement in Transformation Geometry, Geometric Thinking and Attitudes Toward Mathematics and Technology," Thesis, Middle East Technical University, 2014.

[43] P. G. Tieng and L. K. Eu, "Improving Students' Van Hiele Level Of Geometric Thinking Using Geometer's Sketchpad," Malaysian Online J. Educ. Technol., vol. 2, no. 3, pp. 20-31, 2013. [Online]. Available: www.mojet.net.

[44] C. C. Meng and N. Idris, "Enhancing Students' Geometric Thinking and Achievement in Solid Geometry," J. Math. Educ., vol. 5, no. 1, pp. 15-33, 2012.

[45] N. Idris, "The Impact of Using Geometers' Sketchpad on Malaysian Students' Achievement and Van Hiele Geometric Thinking," J. Math. Educ., vol. 2, no. 2, pp. 94-107, 2009.

[46] C. C. Meng, "Enhancing Students' Geometric Thinking Through Phase-Based Instruction Using Geometer'S Sketchpad : a Case Study," J. Pendidik dan Pendidik., vol. 24, pp. 89-107, 2009.

[47] A. H. Abdullah and M. Mohamed, "The Use of Interactive Geometry Software (IGS) to Develop Geometric Thinking," J. Teknol., vol. 49, pp. 93-107, 2008.

[48] N. Idris, "The effect of geometers' sketchpad on the performance in geometry of Malaysian students' achievement and their Van Hiele geometric thinking," Malaysian J. Math. Sci., vol. 1, no. 2, pp. 169-180, 2007.

[49] K. E. Chang, Y. T. Sung, and S. Y. Lin, "Developing geometry thinking through multimedia learning activities," Comput. Human Behav., vol. 23, no. 5, pp. 2212-2229, 2007, doi: 10.1016/j.chb.2006.03.007.

[50] M. Abidin, Z. Ismail, and N. Ismail, "Geometrical Thinking with Technology: A Systematic Literature Review," in 2018 IEEE 10th International Conference on Engineering Education (ICEED), Nov. 2018, pp. 230-235, doi: 10.1109/ICEED.2018.8626949.

[51] G. Keren and M. Fridin, "Kindergarten Social Assistive Robot (KindSAR) for children's geometric thinking and metacognitive development in preschool education: A pilot study," Comput. Human Behav., vol. 35, pp. 400-412, 2014, doi: 10.1016/j.chb.2014.03.009.

[52] F. F. Firmansyah, B. E. Aribowo, R. Damayanti, M. P. Sari, Sunardi, and E. Yudianto, "The matthayom and senior high school student's metacognition profile on solving pisa test shape and space content based on Van Hiele level," J. Phys. Conf. Ser., vol. 1563, p. 012049, Jun. 2020, doi: 10.1088/1742-6596/1563/1/012049. 